\title{
Natural infection of calves by Anaplasma marginale in dairy herds of the Metalúrgica Region, Minas Gerais ${ }^{1}$
}

\author{
Valeska S.P. Melo², Lygia M.F. Passos², Elias J. Facury-Filho², Helton M. Saturnino ${ }^{2}$ \\ \& Múcio F.B. Ribeiro ${ }^{3 *}$
}

\begin{abstract}
Melo V.S.P., Passos L.M.F., Facuri-Filho E.J., Saturnino H.M. \& Ribeiro M.F.B. 2001. Natural infection of calves by Anaplasma marginale in dairy herds of the Metalúrgica Region, Minas Gerais. Pesquisa Veterinária Brasileira 21(4):146-150. Depto Parasitologia, Universidade Federal de Minas Gerais, Cx. Postal 486, Belo Horizonte, MG 31270-910, Brazil.

The dynamic of natural infections by Anaplasma marginale in calves was evaluated during a period of one year on two farms located in the Metalúrgica Region, State of Minas Gerais, Brazil. Blood samples were collected weekly for rickettsemia and packed cell volume (PCV) determination. The animals born from March to July suffered the infection in October and November, independently of their age, whilst calves born from September to December acquired the infection during the first days of life. These animals presented patent rickettsemia from 30 days of life. During the patent period PCV decreased after one week of infection, ranging from 20 to $23 \%$. It was concluded, that in the region studied, the transmission of $A$. marginale is influenced by climatic conditions, and that calves born during the dry season are more likely to acquire the infection when they are exposed to high transmission levels during the subsequent raining season.
\end{abstract}

INDEX TERMS: Anaplasma marginale, anaplasmosis, cattle, epidemiology.

RESUMO.- [Infecção natural por Anaplasma marginale em bezerras de fazendas leiteiras da região Metalúrgica de Minas Gerais.] Realizou-se um estudo da dinâmica de infecções naturais por Anaplasma marginale, durante o período de um ano, em duas propriedades localizadas na Região Metalúrgica do Estado de Minas Gerais. Foram realizados esfregaços sangüíneos e determinação do volume globular (VG). Os animais que nasceram no período de março a julho sofreram a infecção em outubro e novembro, independentemente da idade, enquanto os que nasceram no período de setembro a dezembro adquiriram a infecção nos primeiros dias de vida, com parasitemia patente a partir de 30 dias de idade. Durante o período patente, o VG reduziu na primeira semana de infecção, variando entre 20 a $23 \%$. Concluiu-se que a ocorrência da primo-infecção sofre influência das estações do ano e que bezerros nascidos na estação seca apresentam maior risco de

\footnotetext{
${ }^{1}$ Accepted for publication on July 26, 2001.

${ }^{2}$ Escola de Veterinária, Universidade Federal de Minas Gerais, (UFMG), Belo Horizonte, MG.

${ }^{3}$ Departamento de Parasitologia, Instituto de Ciências Biológicas, UFMG, Cx. Postal 486, Belo Horizonte, MG 31270-901, Brazil.

*Author to whom correspondence should be addressed.
}

infecção, quando expostos às condições de elevada transmissão durante a estação chuvosa subseqüiente.

TERMOS DE INDEXAÇÃO: Anaplasma marginale, anaplasmose, bovinos, epidemiologia.

\section{INTRODUCTION}

Anaplasmosis is a disease of ruminants, characterized by progressive anemia (Ristic 1968). The species that stands out as cause of the disease in cattle is Anaplasma marginale Theiler, 1910. This hemoparasitosis is endemic in tropical and subtropical regions and represents a limiting factor for the development of livestock, due to high mortality rates, reduction in meat and milk production and costs of treatment and control measures (McDowell et al. 1964, Lima 1991).

The State of Minas Gerais has an area of $588,386.6 \mathrm{~km}^{2}$ and an estimated cattle population of 20 million heads, corresponding to $13.1 \%$ of the national herd (IBGE 1996). The climate is characterized by a dry season (Winter) from June to September and a wet season (Summer) from December to March. According to Koppen's classification, Minas Gerais has two climatic areas, one called $\mathrm{CW}$, with temperatures ranging from below $18^{\circ} \mathrm{C}$ in Winter to above $22^{\circ} \mathrm{C}$ in Summer, 
and another called AW with temperatures above $18^{\circ} \mathrm{C}$ in Winter (Antunes 1986).

Climate, soil and cattle biotypes modulate the capacity of the land to support Boophilus microplus (Guglielmone 1995) and hematophagous diptera population, considered the main vectors for bovine anaplasmosis (Yeruham \& Braverman 1981).

Despite the high prevalence of antibodies against $A$. marginale previously reported in the State of Minas Gerais and other States (Ribeiro \& Reis 1981b, Madruga et al. 1985), clinical anaplasmosis has occurred, suggesting situations of enzootic instability. Although the importance of $A$. marginale is recognized, the existing epidemiological data have been limited to certain areas and can not be applied to the whole State. This is due to the existence of different ecological conditions, and also to the different management systems adopted (Ribeiro \& Reis 1981a,b).

The purpose of the present study was to determine the dynamic of $A$. marginale natural infections in a $\mathrm{CW}$ climatic area, during a period of one year, aiming to understand the epidemiology of this disease, providing knowledge for the proposal of effective prevention and control measures for this area.

\section{MATERIALS AND METHODS}

The study was carried out from March/1997 to June/1998 in two dairy farms (A and B), located at $766 \mathrm{~m}$ altitude, $19^{\circ} 27^{\prime} \mathrm{S}$ latitude and $44^{\circ} 14^{\prime} \mathrm{W}$ longitude, with a mean temperature of $21.5^{\circ} \mathrm{C}$, in the Metalúrgica Region of the Minas Gerais State (CW climatic area, Fig. 1).

On Farm A, the newborn female Holstein calves were kept with their respective mothers for two days after birth and then they were transferred to individual pens where they were kept until 30 days of age. The calves received four liters of milk daily and balanced ration ad libitum. After this period, they were transferred to collective pens with restrict access to pasture (twice a week), where they were kept until 90 days of age. During this period they received balanced ration, hay and water ad libitum. The calves were then maintained on star grass pastures, receiving corn silage and concentrate from May to October or pasture plus concentrate from November to April.

On this farm, 55 females calves were divided into two groups, according to the period of their birth:

- Group 1 was composed of 30 animals born from March to July 1997;

- Group 2 was composed of 25 animals born from September to December 1997.

On Farm B, Holstein and Brown Swiss female calves were kept with their respective mothers for two days and were transferred to calf hutches, where they stayed up to 30 days of age, and then they were put on Brachiaria pasture. The management was similar to that described for Farm A. In Farm B, 33 female calves born from March to July 1997 were monitored.

Blood samples were collected weekly over a period of one year. Giemsa stained thin blood smears were prepared and examined microscopically to calculate the rickettsemia. The packed cell volume (PCV) was determined using the microhematocrit technique (Schalm et al. 1975). Serum samples were tested monthly by the indirect fluorescent antibody test (IFAT) in order to measure anti-A. marginale antibody levels (IICA 1987)

Data were analyzed by the Chi-square test (Sampaio 1998).

\section{RESULTS}

During the experimental period, the pluvial precipitation was concentrated from November to March, and a defined dry period occurred from May to August.

From April to August, the mean temperature was below $20^{\circ} \mathrm{C}$ and pluvial precipitation was less than $50 \mathrm{~mm}$, conditions considered unfavorable to the development of the biological cycle of ticks and biting flies. From September on, there was an increase in temperature and rainfall values, generating more favorable conditions for the development of Anaplasma vectors (Fig. 1).

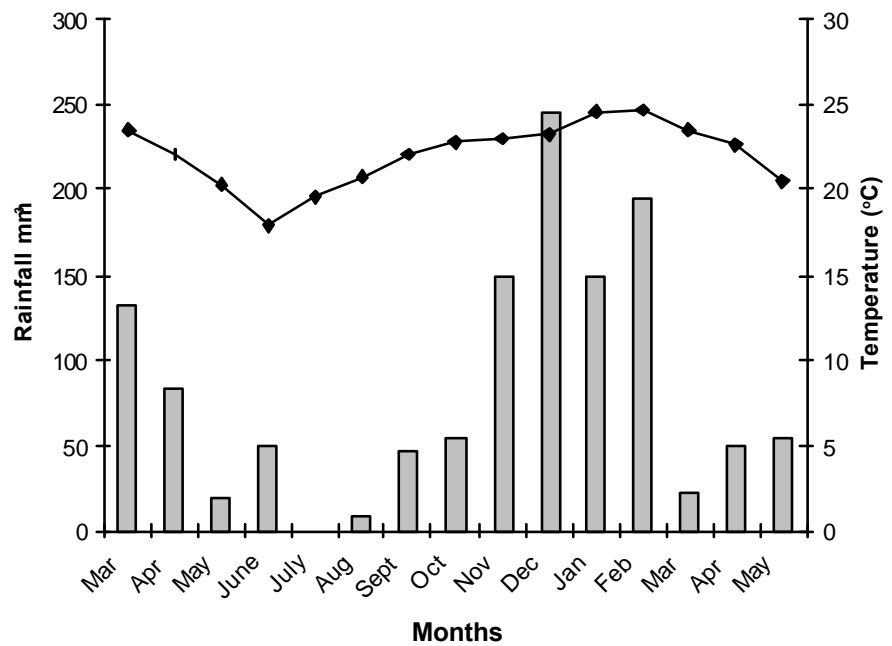

Fig. 1. Temperature and rainfall in the Metalúrgica Region of Minas Gerais, 1997/98.

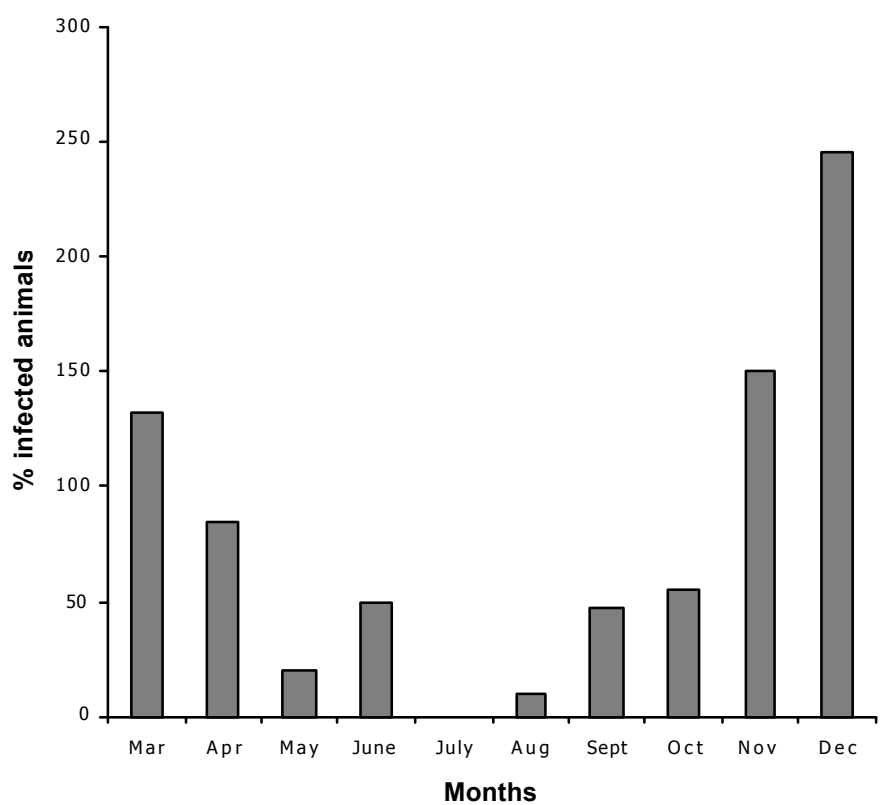

Fig. 2. Anaplasma marginale infection in calves born from March to June $(n=30)$ in Farm A, Metalúrgica Region of Minas Gerais, 1997. 
Table 1. Natural infection of calves by Anaplasma marginale in two dairy herds, in the Metalúrgica Region of Minas Gerais, 1997/98

\begin{tabular}{|c|c|c|c|c|c|c|}
\hline \multirow{3}{*}{$\begin{array}{c}\text { Age } \\
\text { (months) }\end{array}$} & \multicolumn{4}{|c|}{ Farm A } & \multicolumn{2}{|c|}{ Farm B } \\
\hline & \multicolumn{2}{|c|}{ Group 1} & \multicolumn{2}{|c|}{ Group 2} & \multirow{2}{*}{$\begin{array}{c}\text { Infection } \\
((\%)\end{array}$} & \multirow{2}{*}{$\begin{array}{l}\text { Rickettsemia } \\
((\%)\end{array}$} \\
\hline & $\begin{array}{c}\text { Infection } \\
((\%)\end{array}$ & $\begin{array}{l}\text { Rickettsemia } \\
((\%)\end{array}$ & $\begin{array}{c}\text { Tnfection } \\
((\%)\end{array}$ & $\begin{array}{c}\text { Rickettsemia } \\
((\%)\end{array}$ & & \\
\hline$<2$ & 26.7 & 1.8 & 32.0 & 0.6 & 15.1 & 0.9 \\
\hline $3-4$ & 3.3 & 0.4 & 36.0 & 0.7 & 27.3 & 1.8 \\
\hline $5-6$ & 56.7 & 1.3 & 28.0 & 1.4 & 21.2 & 2.9 \\
\hline $7-8$ & 13.3 & 3.8 & 4.0 & 2.7 & 36.4 & 2.8 \\
\hline
\end{tabular}

\section{Farm A}

Among the animals born from March to July (Group 1), $70.0 \%(21 / 30)$ acquired the infection when they were five months old or older (Table 1). The animals had higher levels of infection from October to December, independently of their ages (Fig. 2). The mean rickettsemia ranged from 0.4 to $3.8 \%$, being higher in animals with ages between 7 and 8 months $(\mathrm{p}<0.05)$, during November and December.

Table 2 shows the frequency of positive sera by IFAT among calves in Group 1. The number of positive animals decreased to $13.6 \%$ during the period of 90 to 150 days. Thereafter, the number of positive animals increased gradually, and the highest titers were recorded.

Table 2. Frequency of calves with antiAnaplasma marginale antibodies detected by IFAT on two dairy farms in the Metalúrgica Region of Minas Gerais, 1997/98

\begin{tabular}{ccc}
\hline $\begin{array}{c}\text { Age } \\
\text { (days) }\end{array}$ & Farm $A^{\mathrm{a}}$ & Farm B \\
\hline$<30$ & 90.9 & 81.8 \\
$31-60$ & 68.2 & 63.6 \\
$61-90$ & 27.3 & 45.5 \\
$91-120$ & 13.6 & 30.3 \\
$121-150$ & 13.6 & 45.5 \\
$151-180$ & 81.8 & 63.6 \\
$181-211$ & 96.0 & 66.7 \\
$212-240$ & 98.0 & 81.8
\end{tabular}

a Serological tests were carried out only in Group 1.

In Group 2 (animals born from September to December), $68.0 \%(17 / 25)$ were infected during the first 4 months of life, while the remaining calves were infected when 5 to 8 months old. Maximum infection levels occurred from January to March, when $72.0 \%$ of calves showed rickettsemia (Fig. 3). In this group, the rickettsemia was significantly lower $(\mathrm{p}<0.05)$ than in Group 1 (Table 1).

On Farm A, recrudescence was observed in 22 (40.0\%) among the 55 studied animals, being $8(15.0 \%)$ in calves from Group 1 and $14(25.0 \%)$ in calves from Group 2 . The first recrudescence appeared 30 days after the primary infection, with rickettsemias ranging from $0.03 \%$ to $5.1 \%$. A second recrudescence was observed in $24.0 \%$ of the calves, between 20 and 40 days after the first recrudescence.
The mean PCV, registered before the patent rickettsemia was $33.0 \%$ in both groups. After infection this value decreased to $25.0 \%$ in Group 1, and to $27.0 \%$ in Group 2, and were statistically different $(p<0.05)$ from the values observed before infection. On the other hand, no difference $(p<0.05)$ was observed in PCV during recrudescence.

\section{Farm B}

On farm B, the majority of animals (57.6\%) was infected when they were 5 to 8 months old. The higher infection rates occurred from September to December, when 69.7\% acquired the infection (Fig. 4). The mean rickettsemias ranged between $0.9 \%$ and $2.9 \%$, being higher $(\mathrm{p}<0.05)$ in animals over 5 months of age (Table 1 ). In this group the dynamic of anti- $A$. marginale antibodies was similar to that described for Farm A (Table 2).

Recrudescence was observed in $8(24.0 \%)$, out of 33 animals. The rickettsemias ranged from $0.3 \%$ to $1.5 \%$ and started 20 days after the primary infection.

Before the patent rickettsemia of $A$. marginale, the mean PCV was $32.0 \%$. After rickettsemias, this value decreased to $24.0 \%$ during the first week of infection and was significantly different $(\mathrm{p}<0.05)$ from those observed before infection. The mean PCV value during recrudescence was $25.0 \%$, but no difference $(p<0.05)$ was observed between PCV values during the first infection and recrudescence.

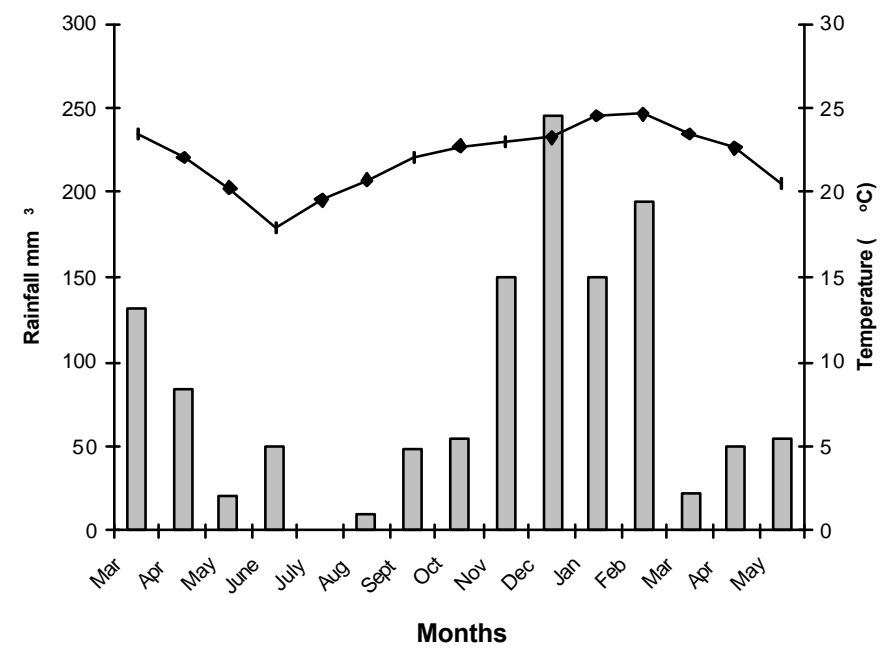

Fig. 3. Anaplasma marginale infection in calves born from September to December $(n=25)$ on Farm A, Metalúrgica Region of Minas Gerais, 1997/98 


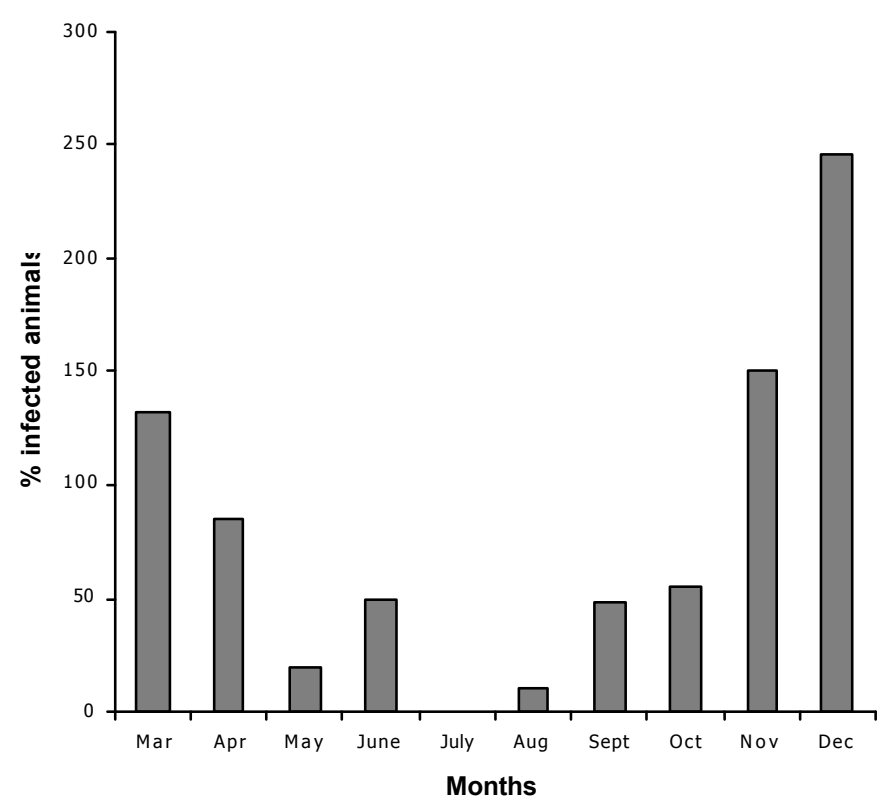

Fig. 4. Anaplasma marginale infection in calves born from March to July ( $n=33)$ on Farm B, Metalúrgica Region of Minas Gerais, 1997.

\section{DISCUSSION}

The epidemiology of anaplasmosis is difficult to understand because the transmission of Anaplasma marginale under natural conditions is not well defined. A. marginale can be transmitted by ticks, as well as by biting flies in tropical and subtropical areas (Wanduragala \& Ristic 1993). Among the species of ticks mentioned as vectors of anaplasmosis, Boophilus microplus has been considered the main transmitter of this rickettsia (Rogers et al. 1978, Hermans et al. 1994). Nevertheless, the transovarian transmission of $A$. marginale in B. microplus is still controversial, since several studies could not demonstrate it, and its occurrence appears to be at low frequency in nature (Potgieter 1979, Ribeiro et al. 1996). The transestadial transmission of anaplasmosis assumes real importance, particularly considering that suckling calves can be infested with ticks from their mothers. The transestadial and intraestadial transmissions are likely to be more frequent in intensive exploitation systems, where a close physical contact among the animals is common, allowing ticks to be transferred (Mason \& Norval 1981, Aguirre et al. 1994).

In the region studied, under natural conditions, B. microplus ticks have four generations during the year. Tick infestation is observed through out the year, with the highest incidence occurring from November to January, when the mean temperature is higher than $20^{\circ} \mathrm{C}$ (Magalhães 1989).

Transmission of $A$. marginale by hematophagous diptera is known to be of importance under field conditions, but no data are available for South America regarding their relevance under local conditions (Guglielmone 1995). As far as flotation of biting fly populations in this area is concerned, there is a seasonal occurrence with two peaks of high incidence, one in October (Spring) and another in January (Summer), when the climatic conditions are favorable for the development of these vectors (Rodriguez 1998).

The region studied is characterized by two well defined seasonal periods, suggesting a direct relationship between climatic conditions and transmission of $A$. marginale.

From March to September (Autumn-Winter) there is a reduction of the population of vectors, caused by less favorable climatic conditions (decrease in temperature and rainfall), which affect their biological life cycle. On both farms, the majority of animals born in this period acquired the $A$. marginale infection at the beginning of October and November, independently of their age. This period coincides with an increase in temperature and the beginning of the rainy season, which results in an increased number of anaplasmosis vectors. At this time, most animals were 6 to 7 months old and were vulnerable to have clinical disease. It is known that susceptibility to anaplasmosis increases with age and with decline of colostral antibodies (Roby et al.1961).

In contrast, animals born from September to December (Group 2) acquired the primary infection during their first days of life. Patent rickettsemias were detected from day 30 and were concentrated in January. These results coincide with previous studies in endemic areas (Corrier \& Guzman 1977, Ribeiro \& Reis 1981a, Madruga et al. 1985).

Comparing the two management systems, it is noticed that on Farm B calves are exposed to the vectors at an early age, as they have access to grass since their first days of life. Under this circumstance the primary infection occurs earlier than that occurring in calves kept in calf hutches.

The results from this study suggest that, in the Metalúrgica Region of the Minas Gerais State, there is a need to adopt preventive measures to protect calves born between April and August from having clinical infections at the beginning of the rainy season. This would help to control the disease, avoiding severe economical losses due to mortality and treatment of a high number of animals.

Acknowledgments.- The authors thank the HMS Agropastoril Ltda and Barreiro Alto for providing the animals and facilities; Ms. Márcia Gomes for technical support and Ms. Nádia Maria Silva for helping editing the figures.

\section{REFERENCES}

Aguirre D.H., Gaido A.B., Vinabal A.E., De Echaide S.T. \& Guglielmone A.A. 1994. Transmission of Anaplasma marginale with adult Boophilus microplus ticks fed as nymphs on calves with different levels of rickettsaemia. Parasite 1:405-407.

Antunes F.Z. 1986. Caracterização climática do estado de Minas Gerais. Inf. Agropec. 12:9-13.

Corrier D.E. \& Guzman S. 1977. The effect of natural exposure to Anaplasma marginale and Babesia infections on native calves in an endemic area of Colombia. Trop. Anim. Health Prod. 9:47-51.

Guglielmone A.A. 1995. Epidemiology of babesiosis and anaplasmosis in South and Central America. Vet. Parasitol. 57:109-119.

Hermans P., Dwinger R.H., Buening G.M. \& Herrero M.V. 1994. Seasonal incidence and hemoparasite infection rates of ixodid ticks (Acari: Ixodidae) detached from cattle in Costa Rica. Rev. Biol. Trop. 42:623-632.

IBGE 1996. Censo Agropecuário de Minas Gerais. Instituto Brasileiro de Geografia e Estatística, Rio de Janeiro.

IICA 1987. Tecnicas para el Diagnóstico de Babesiosis y Anaplasmosis Bovine, 
Instituto Interamericano de Cooperação para la Agricultura, San José, Costa Rica.

Lima J.D. 1991. Premunição: uma alternativa para o controle da tristeza parasitária, p. 39-43. In: 7 ํ Seminário Brasileiro de Parasitologia Veterinária, São Paulo.

Madruga C.R., Kessler R.H., Gomes A., Schenk M.A.M. \& Andrade D.F. 1985. Níveis de anticorpos e parasitemia de Anaplasma marginale em área enzoótica, nos bezerros da raça nelore, ibagé e cruzamentos de nelore. Pesq. Agropec. Bras. 20: 135-142.

Magalhães F.E.P. 1989. Aspectos biológicos, ecológicos e de controle do Boophilus micropulus (Canestrini, 1887) no município de Pedro Leopoldo, MG. Tese de Doutorado, UFMG, Belo Horizonte. 102 p.

Mason C.A. \& Norval R.A.I. 1981. The transfer of Boophilus microplus (Acarina: Ixodidae) from infested to uninfested cattle under field conditions. Vet. Parasitol. 8:185-188.

McDowell R.E., Roby T.O., Fletcher J.L., Foote L.E., Branton C. \& High J.W. 1964. Impact of anaplasmosis in a dairy herd. J. Anim. Sci. 23:168-171.

Potgieter F.T. 1979. Epizootiology and control of anaplasmosis in South Africa. J. Afric. Assoc. 50:367-372.

Ribeiro M.F.B. \& Reis R. 1981a. Prevalência da anaplasmose em quatro regiões do estado de Minas Gerais. Arq. Esc. Vet. UFMG, Belo Horizonte, 33:57-62.

Ribeiro M.F.B. \& Reis R. 1981b. Exposição natural de bezerros em área endêmica de Anaplasma marginale de Minas Gerais. Arq. Esc. Vet. UFMG, Belo Horizonte, 33:63-66.
Ribeiro M.F.B., Lima J.D. \& Patarroyo J.H.S. 1996. Attempted transmission of Anaplasma marginale by infected Boophilus microplus. Braz.J. Vet. Anim. Sci. 48:397-402.

Ristic M. 1968. Anaplasmosis, p. 473-536. In: Weinman D. \& Ristic M. (ed.) Infectious Blood Diseases of Man and Animals. Academic Press, New York.

Roby T.O., Gates D.W. \& Mott L.O. 1961. Comparative susceptibility of calves and adult cattle to bovine anaplasmosis. Am.J.Vet. Res. 22:982-985.

Rodriguez Z.B. 1998. Dermatobia hominis (L. Jr., 1781) (Diptera: Oestridae: Cuterebrinae): ciclo silvestre e ecologia das infestações de bovinos pelo berne no município de Pedro Leopoldo, MG, Brasil. Tese de Doutorado, UFMG, Belo Horizonte. 115 p.

Rogers R.J., Blight G.W. \& Knolt S.G. 1978. A study of the epidemiology of Anaplasma marginale infections of cattle in Southern Queensland. Aust. Vet. J. 54:115-120.

Sampaio I.B.M. 1998. Estatística Aplicada à Experimentação Animal. Fundação de Ensino e Pesquisa em Medicina Veterinária e Zootecnia, Belo Horizonte. 221 p.

Schalm O.W., Jain N.C. \& Carrol E.J. 1975. Veterinary Hematology. Lea \& Febiger, Philadelphia. 807p.

Wanduragala L. \& Ristic M. 1993. Anaplasmosis, p. 65-83. In: Woldehiwt Z., \& Ristic M. (ed.) Rickettsial and Chlamydial Diseases of Domestic Animals. Pergmon Press, Oxford.

Yeruham I. \& Braverman Y. 1981. The transmission of Anaplasma marginaleto cattle by blood-sucking arthropods. Ref. Vet. 38:37-44. 